\title{
Kariyer Psikolojik Danışmanlığı ve Mesleki Rehberlik Alanında Türkiye’de Yayınlanan Makalelerin İncelenmesi
}

\section{Investigation of Articles Published in The Field of Career Counseling and Vocational Guidance in Turkey}

Ersoy ÇARKIT ${ }^{a^{*}}$

${ }^{\text {a } U z m . ~ P s i k o l o j i k ~ D a n ı s ̧ m a n, ~ M i l l i ~ E g ̆ i t i m ~ B a k a n l ı g ̆ ı ~}$

ORCID: 0000-0002-9811-9135

\section{MAKALE BİLGİṠ \\ Makale Geçmişi: \\ Başvuru tarihi: 1 Şubat 2019 \\ Düzeltme tarihi: 04 Ağutos 2019 \\ Kabul tarihi: 23 Ağustos 2019}

Anahtar Kelimeler:

Kariyer Danışmanlığı

Mesleki Rehberlik

Araştırma Eğilimleri

\section{A R T I C L E I N F O}

\section{Article history:}

Received 1 February 2019

Received in revised form 04 August 2019

Accepted 23 August 2019

\section{Keywords:}

Career Counseling

Vocational Guidance

Research Trends
ÖZ

$\mathrm{Bu}$ araştırmanın amacı, 2002-2017 yılları arasında Kariyer Psikolojik Danışmanlığı ve Mesleki Rehberlik alanında Türkiye'de yayınlanan makaleleri inceleyerek bu alandaki araştırma eğilimlerini belirlemektir. $\mathrm{Bu}$ araştırmada Ulusal Akademik Ăg ve Bilgi Merkezi'nde (ULAKBİM) yer alan hakemli dergilerde yayınlanan 93 makale analiz kapsamına alınmıştır. Makaleler "Yayın Kodlama Formu"ndaki araştırma yılı, yazar sayısı, araştırma yöntemi, çalışma grubu, çalışma grubu büyüklüğü ve konu alanları olmak üzere 6 farklı temada değerlendirilmiştir. $\mathrm{Bu}$ çalışma, nitel araştırma yöntemiyle yürütülmüştür. Veriler doküman incelemesi yöntemiyle toplanmış, içerik analizi ve uyum analizi kullanılarak çözümlenmiştir. Araştırmanın sonuçlarına göre; yıllar ve tercih edilen araştırma yöntemleri arasında bir uyum olmadığı tespit edilmiştir. Ayrıca en fazla lise öğrencileri örneklemiyle çalışıldığ en fazla iş doyumu ve mesleki olgunluk konularında çalışmaların yapıldığı tespit edilmiştir.

\section{A B S T R A C T}

The purpose of this paper is to examine the articles in the field of Career Counseling and Vocational Guidance between the years 2002-2017 in Turkey and determine the research trends in this area. In line with this aim, 93 articles published in the National Academic Network and Information Center refereed journals were included in the analysis. The articles were evaluated in 6 different themas including study method, study group, study group size, number of authors and subject areas in "Publication Coding Form". This study was carried out with qualitative research method. Data were collected by document analysis method and analyzed by using content analysis and correspondence analysis. According to the results of correspondence analysis, there was no correspondence between years and preferred methodology. Furthermore, relational researches have been found to be majority. The subjects of job satisfaction and vocational maturity are researched the most.

\section{Giriș}

Bireylere üretken ve gelişmeye açık nitelikleri kazandırmayı amaçlayan çağdaş eğitim anlayışı, bireylerin kendi potansiyelini en yüksek düzeyde gösterebileceği mesleki seçimler yapmalarına ve kariyer gelişimlerini sürdürmelerine önem verir. Bireye bu alanda verilen hizmetler kariyer psikolojik danışmanlığg ve mesleki rehberlik kapsamında yer alır (Yeşilyaprak, 2011: 3). En önemli görevlerinden biri bireylerin kariyer kararı verme süreçlerini anlamalarına yardım etmek olan kariyer psikolojik danışmanlığı ve mesleki rehberlik hizmetlerinin (Duffy ve Sedlacek, 2007: 149) tarih boyunca kültürel, bağlamsal ve örgütsel değişiklikler yaşadığı ve buna karşın

\footnotetext{
* Sorumlu yazar/Corresponding author
} e-posta: ersoy.12@hotmail.com insanlara sunulan mesleki seçimler konusundaki yardım etme tekniklerinde de değişiklikler görüldüğü belirtilmektedir (Savickas, 2008: 97). 1900'dan önceki 50 yıllık dönemde, baskın yardım yaklaşımının o zamanın tarım topluluklarında mentorlük, yirminci yüzyılın ilk yarısında sanayi șehirlerinde mesleki rehberlik, yirminci yüzyılın ikinci yarısında kurumsal toplumlarda kariyer psikolojik danışmanlığg ve 21.yy'ın ilk yarısında küresel ekonomiyle birlikte yapısalcılık kavramları hâkim olmuştur (Savickas, 2008: 97-111). Kisaca, kariyer psikolojik danışmanlığı ve mesleki rehberlik alanındaki yeni eğilimler, ortaya çıktıkları zamanları ve bu zamanların ihtiyaçlarını yansitmaktadırlar (McMahon, 2014: 18). Ayrica kariyer 
psikolojisi alanında birçok kuram geliştirilmiştir. İlk başlarda bireyin özellikleri ile mesleklerin gerekleri hakkında bilgilerin mantıklı bir eşleştirmesine dayanan Parsons'un özellik etmen (Parsons, 1909, 1989'dan aktaran Bacanlı, 2011: 90) kuramı ile kişilik tipi ve çevre arasındaki uyumu dikkate alan Holland'in tip teorisi (Sharf, 2017: 142) kariyer seçimi konusunda içeriğe fazlaca odaklanmasıyla ön plandadır. Sonrasında sürece odaklanan gelişimsel kuramlar geliştirilmiş, 1980-1990 yıllarındaysa içeriğe ve sürece birlikte önem veren, bilişsel süreçleri de dikkate alan bilgi işleme kuramı gibi kuramlar vurgulanmaya başlamıştır (Korkut-Owen ve Niles, 2011: 274). Son zamanlarda değer temelli yaklaşım (Brown, 2002a; Brown ve Crace, 1996), hikâyelendirme yaklaşımı (Brott, 2001; Brott, 2005) ve yaşam düzenleme psikolojik danışmanlığı (Savickas, vd. 2009) gibi yapılandırmacı yaklaşımlar geliştirilmiştir. Devamında geliştirilen kariyer yapılandırma kuramı (Savickas, 2002) ve sistemler kuramı çerçeve çalışması (Patton ve McMahon, 1999) ise kariyer psikolojik danışmanlığı alanındaki mevcut kuramların işlevsel yönlerini bütünleştirmeyi benimsemektedir (Korkut-Owen ve Niles, 2011: 275). Türkiye'de de, ABD model alınarak, mesleki rehberlik ve kariyer psikolojik danışmanlığı alanında öncü adımlar, kararsız adımlar ve sistematik adımlar şeklinde belli aşamalardan geçildiği söylenebilir. $\mathrm{Bu}$ dönemlerde sırasıyla meslek seçimi ve yönlendirme, ilgi ve yeteneklerin erken tespiti, mesleki gelişim ve mesleki gelişim görevleri vurgulanmıştır (Yeşilyaprak, 2012: 101-103). Kariyer psikolojik danışmanlığ 1 ve mesleki rehberlik alanında yaşanan bu değişism ve gelişmelerin, kendisini araştırma eğilimlerinde de kaçınılmaz olarak göstereceği açıktır.

Kariyer psikolojik danışmanlığı ve mesleki rehberlik alanında yürütülen araştırmalarda tercih edilen araştırma yöntemlerindeki ilginin de benzer şekilde yön değiştirmesi beklenmektedir. Modern ve post modern bilim anlayışları, kariyer psikolojik danışmanlığı ve mesleki rehberlik alanında yürütülen araştırmalarda kendini göstermektedirler. Modern bakış açısının temelini, bireyin davranışlarının gözlemlenebileceği, ölçülebileceği ve ön görülebileceği pozitif dünya görüşü oluşturmaktadır. $\mathrm{Bu}$ nedenle modern araştırma yöntemi mutlak bir şekilde deneysel ve nesneldir (Brown, 2002b: 12-13). Kariyer psikolojik danışmanlığı ve mesleki rehberlik araştırmalarında ortaya çıkan post modern etki ise; öznelliği, bakış açısını, çoklu gerçekliği, yorumlamayı ve bağlamı vurgulamaktadır (Watson ve McMahon, 2005). Sonuç olarak, post modern araştırma yöntemi nicelden ziyade niteldir (McMahon ve Watson, 2007: 171). Kariyer psikolojik danışmanlığı ve mesleki rehberlik araştırmaları, deneysel ve nesnel yöntemlere vurgu yaparak modern çağın kökenlerini yansitsa bile kariyer teorisi ve pratiği, yapılandırmacı model ve yaklaşımları geliştirip benimseyerek güçlenmeye başlamıştır (McMahon vd. 2006: 26). Genel olarak değerlendirildiğinde; kariyer psikolojik danışmanlığı ve mesleki rehberlik alanında modellerin, yöntemlerin, araçların güncel ilgisinin ve araştırma eğilimlerinin gözden geçirilmesi gerektiği düşünülmektedir.

Türkiye'de, Psikolojik Danışma ve Rehberlik (PDR) alanında güncel araştırma eğilimlerini belirlemeye yönelik birçok çalışmanın olduğu görülmektedir. Güven, Kısaç, Ercan ve Yalçın (2009: 81-82), Türk PDR Dergisi'nin ilk otuz sayısında yayınlanan 198 makaleyi incelemişlerdir.
Araștırma sonucunda makalelerin çoğunlukla; mesleki rehberlik ve evlilik konularında olduğu, betimsel araştırmalar ile tek yazarlı araştırmaların yoğunlukta olduğu tespit edilmiştir. Benzer şekilde Seçer, Ay, Ozan ve Yılmaz (2014: 49) PDR alanındaki araştırma eğilimlerini belirlemek için 2007-2011 yılları arasındaki yayınlanan 250 makaleyi incelemişlerdir. Araştırma sonucunda, makalelerin ağırlıklı olarak araştırma inceleme temelli betimsel çalışmalar olduğu, veri toplamada anket ve ölçeklerin daha fazla tercih edildiği ve çalışma grubu olarak daha çok lisans öğrencilerinin tercih edildiği belirlenmiştir. Güven, Aslan ve Yıldız-Akyol'un ise (2017: 136) 20002016 yılları arasında Türkiye'de PDR alanında yapılan 255 doktora tezi üzerinde çalıştıkları görülmektedir. Yıllara göre en sık çalışılan konuların, 2000-2005 yılları arasında kayg1 ve stres, psikolojik belirtiler ve depresyon; 20062010 y1lları arasında kayg1 ve stres, saldırganlık, sosyal beceriler ve öfke; 2011-2016 yılları arasında ise kaygı ve stres, saldırganlık- şiddet ve öznel iyi oluş olduğu tespit edilmiştir. Güven ve Aslan (2018: 597-598) tarafindan yapılan başka bir araştırmada ise daha geniş bir inceleme yapıldığı dikkat çekmektedir. Türkiye'de PDR alanında bilimsel dergilerde yayınlanan makaleleri incelemek adına 2012-2016 yılları arasında 23 dergi ve bu dergilerde yayınlanan 441 makalenin incelenmesi sonucunda, bu alandaki makalelerin daha çok nicel araştırmalardan oluştuğu görülmüştür. Çalışmaların çoğunluğunun konu alarak olarak kişisel-sosyal rehberlik alanında olduğu, en az çalışmanın ise aile-evlilik ve mesleki rehberlik alanlarında olduğu sonucuna ulaşılmıştır. Türkiye'de, PDR alanında yayınlanan çalışmalarda kullanılan araştırma yöntem veya desenlerinin de odak noktası olarak tercih edildiği, belirli bir yöntem veya desen kullanılarak alanda yürütülen çalışmaların güncel eğilimlerini belirlemek için de araştırmalar yapıldığı görülmektedir. Keldal ve Bilge (2016: 648), PDR alanında yayınlanan 2010-2015 y1lları arasında yer alan ve karma yöntem kullanılan makaleleri incelemişlerdir. Sonuçta, yayımlanan 242 makaleden 9'unun karma yöntemli olduğu belirlenmiştir. Çalışmaların konu dağılımının pozitif psikoloji, güvengenlik, ilişki doyumu, çatışma çözme becerisi, karar verme becerisi, akademik erteleme ve öfke kontrolü alanlarında yoğunlaştığı görülmüştür. Benzer bir araştırmada Türk ve Cihangiroğlu (2018: 276), uygulamalı PDR lisansüstü tezlerini (268 adet) tematik ve metodolojik olarak incelemişlerdir. Araştırma sonucunda lisansüstü tezlerin yaklaşık \%10'unda aile, evlilik, aile eğitimi konularında çalışıldığı tespit edilmiştir. Bu konu alanını sırasıyla iletişim, empati ve sosyal beceri, akran arabuluculuk, çatışma çözme ve mesleki rehberlik, kariyer danışmanlığ izlemektedir. Yöntemsel açıdan ise daha çok, ön test son test kontrol gruplu deneysel desenin kullanıldığı bulgusuna ulaşılmıştır. Demirtaş-Zorbaz, Kızıldağ ve Voltan-Acar (2016: 1770) ise 1978-2012 yılları arasında lisansüstü düzeyde hazırlanan grupla psikolojik danışma, grup rehberliği ve psiko-eğitsel temelli çalışmalara odaklanmışlardır. $\mathrm{Bu}$ kapsamda 93 lisansüstü tez çalışmasını incelenmiş ve sonuç olarak en fazla ergen, en az yaşlı örneklem üzerinde çalışıldığ 1 görülmüştür. Grupların en fazla bilişsel davranışçı yaklaşım, en az psikanalitik yaklaşım temelli çalışmalar olduğu sonucuna ulaşılmıştır. Journal of Counseling Psychology ile Türk PDR Dergisi'nde, 2006-2015 yılları arasındaki makalelerin karşılaştırmalı olarak incelenmesi de yapılmıştır. Güven, 
Özhan, Kaynak ve Kurt Demirbaş (2018: 198-199) tarafindan yapılan bu araştırmada, 729 makale incelenmiş ve her iki dergide de yayınlanan makalelerin çoğunlukla iki yazarlı olduğu ve ağırlıklı olarak ilişkisel yöntemin kullanıldığı tespit edilmiştir. Türkiye'de kariyer danışmanlığı alanındaki lisansüstü tezlerin araştırma eğilimleri ise Çarkıt (2019) tarafından incelenmiş ve en fazla ilişkisel yöntemlerin kullanıldığı, Sosyal Bilişsel Kariyer Kuramı ile ilgili kavramların çoğunlukla tercih edildiği, lise öğrencilerinin en fazla tercih edilen çalışma grubu olduğu sonucuna varılmıştır.

Türkiye'de PDR alanında tamamlanan lisansüstü tezlerin ve yayınlanan makalelerin araştırma eğilimlerini belirlemeye yönelik çalışmalar olmasına karşın, kariyer psikolojik danışmanlığı ve mesleki rehberlik alanında yayınlanan makalelerin araştırma eğilimlerini belirlemeye yönelik herhangi bir çalışmanın yapılmamış olduğu dikkat çekmektedir. Bu araştırmanın temel amacı ise, 2002-2017 yılları arasında kariyer psikolojik danışmanlığı ve mesleki rehberlik alanında, Ulusal Akademik A $\breve{g}$ ve Bilgi Merkezi (ULAKBIM) veri tabanları üzerinde yer alan hakemli dergilerde yayınlanan makaleler inceleyerek Türkiye'de kariyer psikolojik danışmanlığı ve mesleki rehberlik alanındaki güncel araştırma eğilimleri nasıldır? sorusuna yanıt aramaktır. $\mathrm{Bu}$ doğrultuda; kariyer psikolojik danışmanlığı ve mesleki rehberlik alanında yayınlanan makalelerin; (a) araştırma yılı, (b) yazar sayısı, (c) araştırma yöntemi, (d) çalışma grubu, (e) çalışma grubu büyüklüğü ve (f) konu alanları bakımından görünümü nasıldır? (g) Kariyer psikolojik danışmanlığı ve mesleki rehberlik alanında yayınlanan makalelerde tercih edilen araştırma yöntemleri ve makalelerin yayınlandığı yıllar arasında bir uyum (ilişki) var mıdır? sorularına yanıt aranmıştır.

$\mathrm{Bu}$ araştırma, kariyer psikolojik danışmanlığı ve mesleki rehberlik alanında yayınlanmış makalelerin ayrıntılı görünümünü vermesi bakımından önemli olduğu gibi, kariyer psikolojik danışmanlı̆̆ 1 ve mesleki rehberlikle ilgili konularında çalışan araştırmacıların, hangi araştırma yöntemlerine ne derece öncelik verdiğinin ve zaman içinde araştırma paradigmaları ile yöntemlerinin tercihinde değişiklik olup olmadığının belirlenmesi açısından da önemlidir. Ayrıca sonuçların, araştırmacıları farklı yöntemler kullanmaya ve farklı bilme yolları aramaya motive etmesi beklenmektedir.

\section{Yöntem}

\subsection{Araştırma Modeli}

Nitel araştırma yöntemi temel alınarak yürütülen bu araştırmada, veri toplama yöntemi olarak doküman incelemesi kullanılmıştır. Doküman incelemesi, araştırma veri kaynağı olarak çeşitli metin formlarının toplanması, gözden geçirilmesi, sorgulanması ve analiz edilmesidir (O'Leary, 2004: 177). Bu araştırmada doküman incelemesi yoluyla toplanan veriler (makaleler) çalışma gruplarına, çalışma grubu büyüklüğüne, yazar sayılarına, yayın yılına, araştırma yöntemlerine ve konu başlıklarına göre incelenmiş ve bu inceleme sonucunda elde edilen veriler içerik analizi ve uyum analizine tabi tutulmuştur.

\subsection{Araştırmanın Kapsamı}

$\mathrm{Bu}$ araştırmada, Ulusal Akademik A $\breve{g}$ ve Bilgi Merkezi (ULAKBIM) tarafindan taranan hakemli dergilerde, 20022017 yılları arasında yayınlanan makaleler analiz kapsamına alınmıştır. Ulaşılan makaleler araştırma kapsamına dâhil edilirken yazarlarından en az birinin PDR alanında görev yapıyor olması ya da bu alanda eğitim görmüş olması şartı göz önünde bulundurulmuştur. $\mathrm{Bu}$ kapsamda toplam 93 makale araştırma kapsamına dâhil edilmiş ve incelenmiş̧ir.

\subsection{Veri Toplama Süreci}

Araştırmaya dâhil edilen çalışmalara ulaşmak için internet ortamında Ulusal Akademik Ağ ve Bilgi Merkezi (ULAKBIM) veri tabanlarından yararlanılmıştır. İlgili yayınlara ulaşmak için veri toplama işlemi 19 Mart 2018-16 Nisan 2018 tarihleri arasında gerçekleştirilmiştir. 2018 yılının yaklaşık dört aylık kısmında yayınlanan makalelerin 2018 yılını doğru bir şekilde yansıtamayacağı düşünüldüğü için yayın yılı üst sınır 2017 yılı olarak belirlenmiştir. Veri toplama işleminin gerçekleştirildiği tarihte ULAKBİM üzerinden 2002 yılına kadar olan makalelere ulaşılabildiği için yayın yılı alt sınır 2002 yılı olarak belirlenmiştir. Veri toplama arac1 olarak "Yayın Kodlama Formu" kullanılmıştır. Yayın kodlama formu oluşturulurken alan yazın taraması yapılarak benzer araştırmalarda en çok hangi temaların incelendiği dikkate alınmıştır. Ayrıca iki farklı uzmandan görüş alınarak formun son şekli verilmiştir. Yayın Kodlama Formu; araştırma yılı, yazar sayısı, araştırma yöntemi, çalışma grubu, çalışma grubu büyüklüğü ve konu alanları olmak üzere 6 farklı temadan oluşmaktadır. Ulusal Akademik A $\breve{g}$ ve Bilgi Merkezi üzerinden ulaşılan 93 makale tek tek incelenerek Yayın Kodlama Formu'na işlenmiştir.

\subsection{Verilerin Analizi}

Verilerin çözümlenmesinde SPSS 23 paket programından ve Microsoft Excel programından yararlanılmıştır. Ulaşılan veriler, betimsel içerik analizi ve uyum analizi (correspondence analysis) ile çözümlenmiştir. İçerik analizi, verilerin ana içerik ve mesajlarının özetlenmesi ve raporlanması sürecini tanımlar (Flick 1998 ve Mayring 2004'ten aktaran Cohen, Manion ve Morrison, 2007: 475). Araştırma kapsamındaki 93 makale içerisinden rastgele seçilen beş makale Yayın Kodlama Formu'nda belirtilen başlıklara göre kodlaması için iki farklı alan çalışanına gönderilmiş ve birbirlerinden bağımsız olarak kodlamaları istenmiştir. Yapılan kodlamaların uyum içinde olduğu görülmüştür. Ardında Yayın Kodlama Formu'ndaki bilgiler Microsoft Excel dosyasına işlenmiştir. Ayrıca, teyit edilebilirliği sağlamak için bu belge saklanmaktadır. Araştırma yılı, yazar sayısı, araştırma yöntemi, çalışma grubu, çalışma grubu büyüklüğü ve konu alanlarına göre analiz edilen veriler Microsoft Excel programının filtreleme özelliği kullanılarak kategorilerin sıklıkları belirlenmiştir. Sonrasında her bir tema alanı için kategori ve sıklık tablosu oluşturularak sonuçlar değerlendirilmiştir. Araştırmada kullanılan bir diğer analiz yöntemi ise uyum analizidir (correspondence analysis). Açıklayıcı bir teknik olarak uyum analizi ise iki ya da daha çok kategorik verinin uyumunu (ilişkisini) inceler (Bartholomew, Steele, Muostaki ve Galbraith, 2008: 83). Uyum analizi, çapraz 
tablolara dönüştürülmüş kategorik veya kategorileștirilmiş verileri analiz etmenin ve sonuçları grafiksel olarak göstermenin bir yoludur (Johnson ve Wichern, 2007: 716). $\mathrm{Bu}$ araştırmada satırları yıllar (2002-2017 yılları arası), sütunları ise makalelerde tercih edilen yöntemler (ilişkisel, betimsel, deneysel, nitel, karma, derleme, ölçek geliştirme ve ölçek uyarlama) oluşturmaktadır.

\section{Bulgular}

Araştırmanın bu bölümünde, Yayın Kodlama Formu'ndaki her bir tema için analizler sonucunda elde edilen bulgular tablo (sıklı tablosu), grafik ve şekillerle verilerek yorumlanmıştır.

Tablo 1. Makalelerin Çalışma Gruplarına İlişkin Elde Edilen Bulgular

\begin{tabular}{cc}
\hline Kategori & Sıklık (f) \\
\hline Lise Öğrencileri & 26 \\
Üniversite Öğrencileri & 19 \\
Öğretmenler & 13 \\
Ortaokul Öğrencileri & 11 \\
Rehber Öğretmenler & 7 \\
Akademisyenler & 5 \\
Okul Yöneticileri & 3 \\
Emniyet Personeli & 2 \\
Banka çalışanları & 1 \\
Kadın Gazeteciler & 1 \\
İlkokul Öğrencileri & 1 \\
Aile Mahkemesi Uzmanları (Psikolog) & 1 \\
\hline
\end{tabular}

Tablo 1 'e göre, kariyer psikolojik danışmanlığı ve mesleki rehberlik alanında yayınlanan makalelerin çalışma grupları verilmektedir. Tablo 1 incelendiğinde; ilkokuldan 1 , ortaokuldan 11, liseden 26, üniversite öğrencilerinden 19 , rehber öğretmenlerden 7, öğretmenlerden 13, aile mahkemesi uzmanlarından (psikolog) 1, banka çalışanlarından 1, okul yöneticilerinden 3, akademisyenlerden 5, emniyet personelinden 2 ve kadin gazetecilerden $1 \mathrm{kez}$ çalışma grubu seçildiği görülmektedir. Bulgulardan yola çıkarak en çok lise öğrencilerinden ve üniversite öğrencilerinden çalışma grubu seçildiği görülmektedir.
Tablo 2. Makalelerin Çalışma Gruplarının Büyüklüğüne İlişkin Elde Edilen Bulgular

\begin{tabular}{cc}
\hline Kategoriler & Siklık (f) \\
\hline $201-300$ aras1 & 16 \\
$301-400$ aras1 & 14 \\
$101-200$ aras1 & 13 \\
$51-100$ aras1 & 9 \\
$10-50$ aras1 & 7 \\
$401-500$ aras1 & 7 \\
$501-600$ aras1 & 6 \\
$1001+$ & 5 \\
$601-700$ aras1 & 3 \\
$901-1000$ aras1 & 3 \\
$701-800$ aras 1 & 1 \\
1 & 1 \\
\hline
\end{tabular}

Tablo 2'ye göre kariyer psikolojik danışmanlığı ve mesleki rehberlik alanında çalışma grubu sayısı 1 olan 1 makale, 10-50 arasinda olan 7 makale, 51-100 arasinda olan 9 makale, 101-200 arasında olan 13 makale, 201-300 arasında olan 16 makale, 301-400 arasinda olan 14 makale, 401-500 arasında 7 makale, 501-600 arasında olan 6 makale, 601700 arasinda olan 3 makale, 701-800 arasinda olan 1 makale, 901-1000 arasında olan 3 makale ve 1001 üzerinde olan 5 makale bulunmaktadır. Görüldüğü gibi en fazla araştırma, 201-300 arasında katılımcı ile yürütülmüştür.

Tablo 3. Makalelerin Yazar Sayısına Göre Dağılımı

\begin{tabular}{cc}
\hline Yazar Sayısı & Sıklık (f) \\
\hline Tek yazarlı & 36 \\
2 yazarlı & 36 \\
3 yazarlı & 14 \\
4 yazarlı & 4 \\
5 yazarlı & 2 \\
6 ve üzeri yazarlı & 1 \\
\hline
\end{tabular}

Tablo 3 'e bakıldığında kariyer psikolojik danışmanlığı ve mesleki rehberlik alanında yayınlanan makalelerin 36's1 tek yazarlı, 36'sı 2 yazarl1, 14'ü 3 yazarlı, 4'ü 4 yazarl1, 2'si 5 yazarlı ve 1'i 6 ve üzeri yazarlıdır. Bulgulardan hareketle kariyer psikolojik danışmanlığı ve mesleki rehberlik alanında yayınlanan makalelerin çoğunluğunun tek yazarlı ve iki yazarlı olduğu, 6 ve üzeri yazarlı makalelerinse oldukça az olduğu görülmektedir.

Tablo 4. Y1l-Yöntem Çapraz Tablo

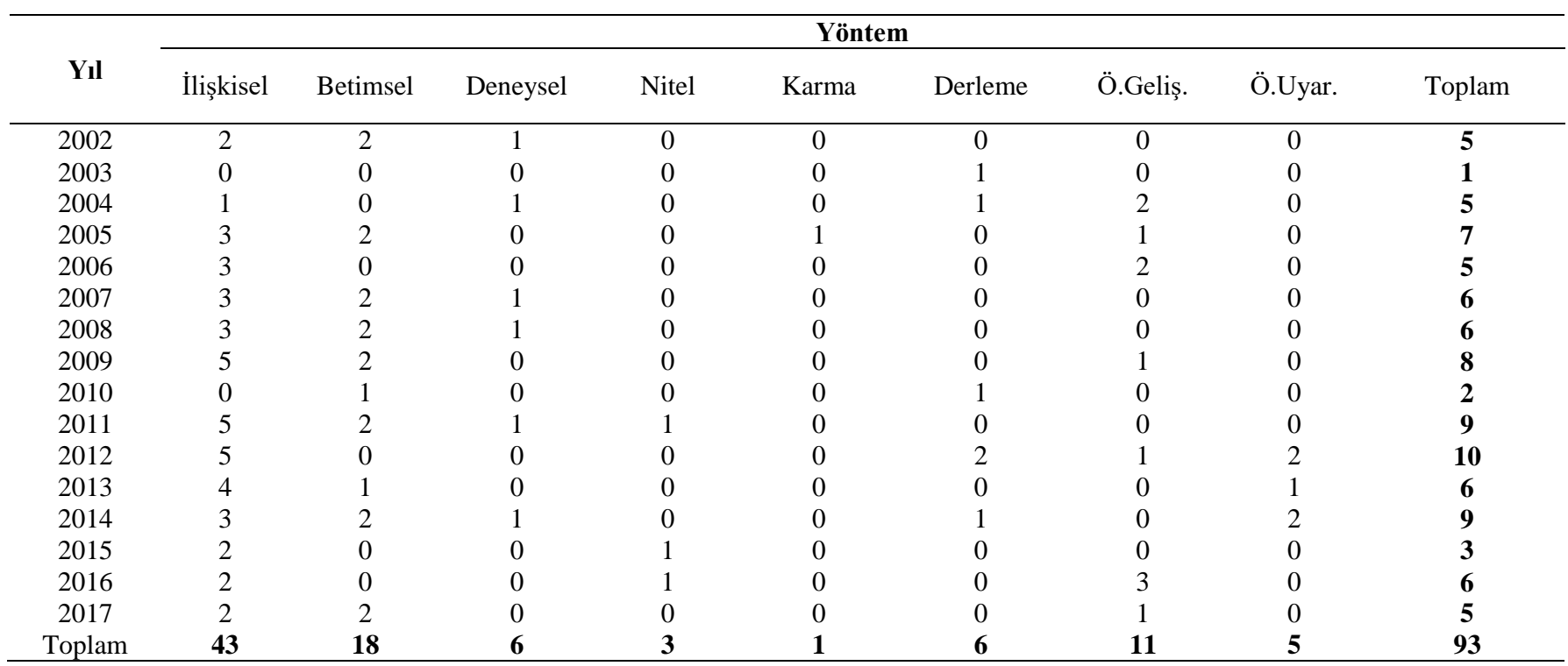


Tablo 4 incelendiğinde kariyer psikolojik danışmanlığı ve mesleki rehberlik alanında yayınlanan makalelerin 5'i 2002 yılında, 1'i 2003 yılında, 5'i 2004 yılında, 7'si 2005 yılında, 5'i 2006 yılında, 6's1 2007 y1lında, 6's1 2008 y1lında, 8'i 2009 yılında, 2'si 2010 yilında, 9'u 2011 yilında, 10'u 2012 yılında, 6'sı 2013 yılında, 9'u 2014 yılında, 3'ü 2015 y1lında, 6's1 2016 y1lında ve 5'i 2017 y1lında yayınlanmıştır. Tablo 4'ten görülebileceği gibi yayınlanan makale sayıları her yıl değişmiştir. En çok makale 2012 yılında ve en az makale 2003 yılında yayınlanmıştır. Tablo 4'e göre kariyer psikolojik danışmanlığı ve mesleki rehberlik alanında yayınlanan makalelerin 43'ünün ilişkisel, 18'inin betimsel, 6'sının deneysel, 3'ünün nitel, 1'inin karma, 6'sının derleme, 11'inin ölçek geliştirme ve 5'inin ölçek uyarlama olduğu görülmektedir. $\mathrm{Bu}$ bulgulardan hareketle makalelerde en fazla ilişkisel ve betimsel yöntemlerin tercih edildiği, en az ise nitel ve karma yöntemlerin tercih edildiği görülmektedir. Tablo 4'te özetlenen sonuçlar, her bir yöntemin yayınlanmış makalelerde her yıl için tercih edilme sayılarını da göstermektedir. Kariyer psikolojik danışmanlığı ve mesleki rehberlik alanında yayınlanan makalelerde tercih edilen yöntemlerin yıllara göre tercih edilme yüzdelerini gösteren çizgi grafiği aşağıda verilmiştir.

Grafik 1. Kariyer psikolojik danışmanlığı ve mesleki rehberlik ile ilgili yayınlanan makalelerde tercih edilen yöntemlerin yıllara göre değişimi

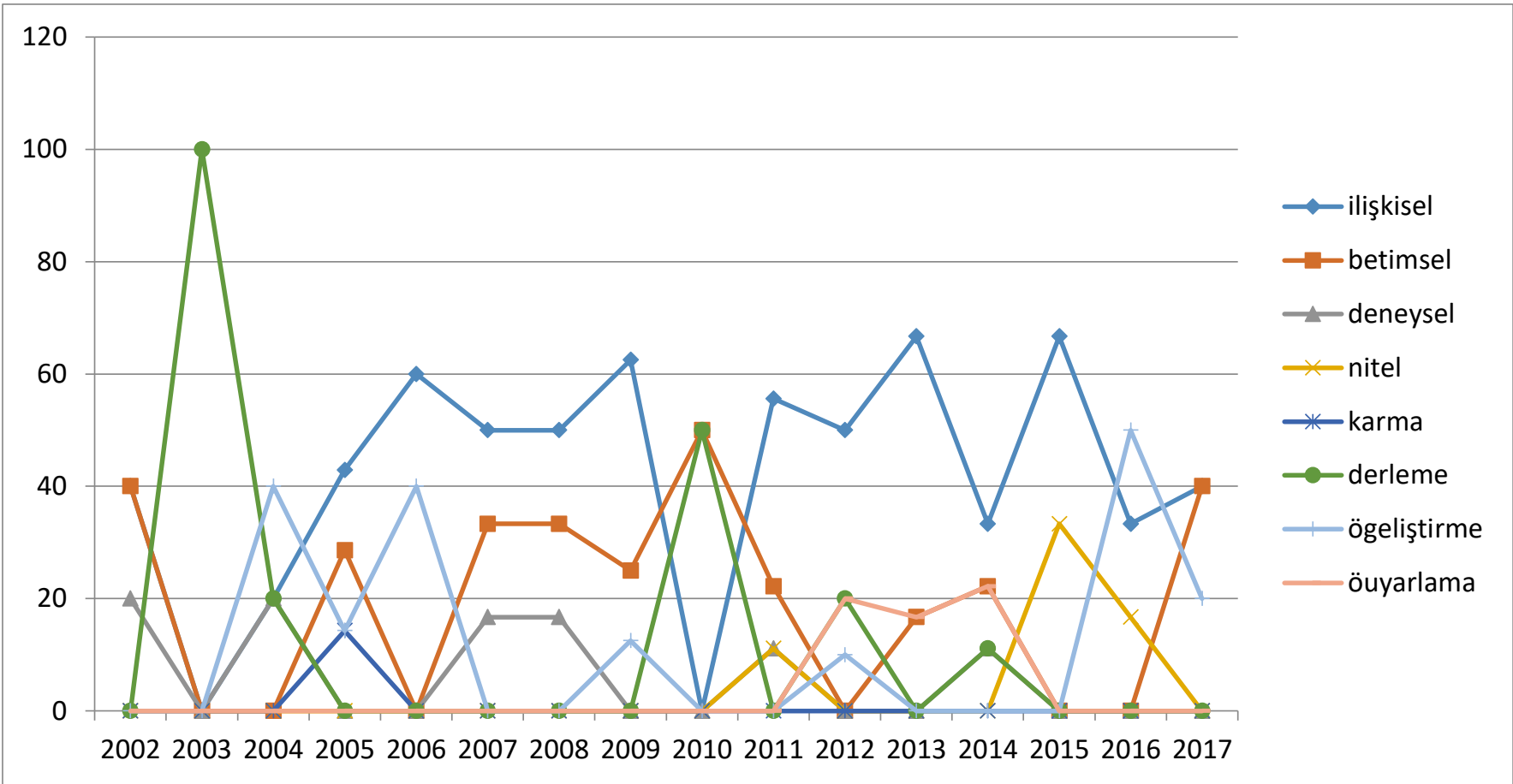

Grafik 1'de görülebildiği gibi, tercih edilen herhangi bir yöntemin yıllar boyunca artma veya azalma eğiliminde olmadığı söylenebilir. Tercih edilen araştırma yöntemlerinin, yıllara göre kullanılma yüzdelerinde artma ve azalmalar sıç̧a görülmektedir.

Tablo 5. Uyum Analizi (Correspondance analysis) Sonuçları

\begin{tabular}{|c|c|c|c|c|c|c|}
\hline \multirow{2}{*}{ Boyut } & \multirow{2}{*}{ Tekil Değer } & \multirow{2}{*}{ İnertia } & \multirow{2}{*}{$\chi^{2}$} & \multirow[b]{2}{*}{$\mathbf{p}$} & \multicolumn{2}{|c|}{ İnertia oranı } \\
\hline & & & & & Açıklanan (\%) & Toplam (\%) \\
\hline 1 & 607 & ,368 & & & ,300 & ,300 \\
\hline 2 & ,549 & ,302 & & & ,245 & ,545 \\
\hline 3 &, 430 &, 185 & & &, 150 & 695 \\
\hline 4 & ,393 &, 155 & & &, 126 &, 821 \\
\hline 5 &, 357 &, 128 & 114,343 &, 251 &, 104 & ,925 \\
\hline 6 & ,244 &, 060 & & & ,049 & ,973 \\
\hline 7 & ,182 & ,033 & & & ,027 & 1,000 \\
\hline Toplam & & 1,229 & & & 1,000 & 1,000 \\
\hline
\end{tabular}

Tablo 5 incelendiğinde inertianın 0'dan farklı olup olmadığına yönelik olarak yürütülen ki-kare testi sonucunda toplam inertianın 0'dan farklı olmadığı görülmektedir $\left(\chi^{2}(105)=114.343, \quad \mathrm{p}>.05\right)$. Buna göre satır ve sütun değişkenleri arasında bir uyum (ilişki) olmadığı, satır ve sütunların birbirinden bağımsız olduğu söylenebilir. Şekil 1 'de uyum analizi sonuçlarının iki boyutlu düzlemde gösterimi sunulmuştur. 
Şekil 1. Uyum analizi sonuçlarının iki boyutlu düzlemde gösterimi
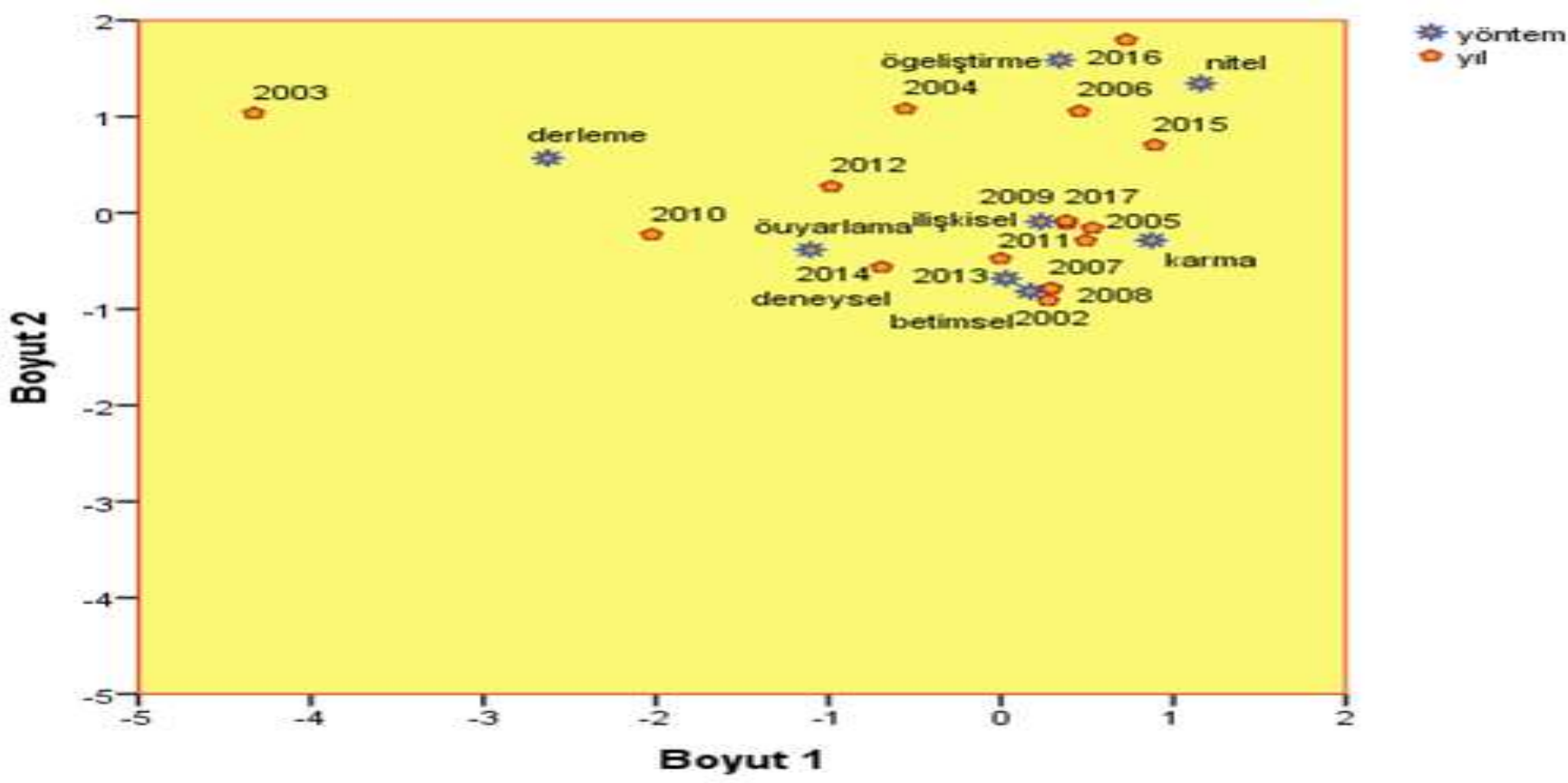

Şekil 1'de görüldüğü gibi yıllar ve araştırma yöntemlerini ifade eden bütün noktalar genel olarak birbirine çok yakın

konumlanmıştır. $\mathrm{Bu}$ nedenle yıllar ile araştırma yöntemlerinin etkileşimini gösteren belirgin bir boyutlandırmanın yapılamayacağı söylenebilir.

Tablo 6. Makalelerin Konu Alanına İlişkin Elde Edilen Bulgular

\begin{tabular}{|c|c|c|c|}
\hline Kategoriler & Sıklık (f) & Kategoriler & Sıklık (f) \\
\hline İş doyumu & 21 & $\begin{array}{l}\text { Mesleki olgunluk/ Mesleki/Kariyer } \\
\text { gelişim(i) }\end{array}$ & 14 \\
\hline Kariyer karar verme yetkinliği & 6 & Mesleki tükenmişlik & 5 \\
\hline Kariyer karar verme stilleri & 5 & Kariyer karar verme & 4 \\
\hline Kariyer kararsızlı̆̆1 & 4 & Mesleki rehberlik hizmetleri & 4 \\
\hline Kariyer karar verme güçlükleri & 4 & Mesleki kișilik & 4 \\
\hline Alan seçimi & 3 & Mesleki doyum & 4 \\
\hline Çalıșma anlayıșı & 2 & Mesleki değer & 2 \\
\hline Kariyer kaygisi & 2 & Mesleki yönelim & 1 \\
\hline Kariyer geleceği & 1 & İș umudu & 1 \\
\hline Yetenekler & 1 & Mesleki ilgi & 1 \\
\hline $\begin{array}{l}\text { Duygusal ve kişilik ilişkili kariyer karar verme } \\
\text { güçlükleri }\end{array}$ & 1 & Kariyer araştırma yetkinlik beklentisi & 1 \\
\hline Kariyer yelkenlisi modeli & 1 & Kariyer psikolojik danıșma ihtiyaçları & 1 \\
\hline Umut odaklı kariyer psikolojik danışma & 1 & $\begin{array}{l}\text { Meslek seçimine ilişkin akılcı olmayan } \\
\text { inançlar }\end{array}$ & 1 \\
\hline Meslek tanıtımı & 1 & Meslek seçimi bilgi kaynakları & 1 \\
\hline Mesleki dayanıklılık & 1 & Kaos kuramı & 1 \\
\hline Mesleki sonuç beklentisi & 1 & Mesleki grup rehberliği & 1 \\
\hline
\end{tabular}

Tablo 6 incelendiğinde kariyer psikolojik danışmanlığı ve mesleki rehberlik alanında en fazla çalışılan kavramların iş doyumu ve mesleki olgunluk kavramları olduğu görülmektedir. Bu kavramların yanı sıra kariyer gelişimi, kariyer karar verme sitilleri, mesleki tükenmişlik ve kariyer karar verme yetkinliği kavramlarının da en çok çalışılan kavramlar arasında olduğu görülmektedir.

\section{Tartışma ve Sonuç}

$\mathrm{Bu}$ araştırmanın amacı, kariyer psikolojik danışmanlığı ve mesleki rehberlik alanında Türkiye'de yayınlanan makaleleri sistematik olarak gözden geçirmek ve bu alandaki ilgili eğilimleri belirlemektir.
Kariyer psikolojik danışmanlığı ve mesleki rehberlik alanında yayınlanan makalelerin yıllara göre görünümü ile ilgili olarak; en fazla makalenin 2012 y1lında, en az makalenin ise 2003 yılında yayınlandığı sonucuna ulaşılmıştır. Kariyer psikolojik danışmanlığı ve mesleki rehberlik alanında Türkiye'de en fazla lisansüstü tezin 2014 yılında yapıldığ 1 , 2004 yllında ise alanla ilgili herhangi bir lisansüstü tezin yapılmadığı bir başka çalışmada bulunmuştur (Çarkıt, 2019). Belirlenen yılların birbirine yakın zamanlar olduğu söylenebilir.

Kariyer psikolojik danışmanlığı ve mesleki rehberlik alanında yayınlanan makalelerde tercih edilen araştırma yöntemlerinin görünümü ile ilgili olarak; makalelerin 43'ünün ilişkisel, 18'inin betimsel, 6'sının deneysel, 3'ünün nitel, 1'inin karma, 6'sının derleme, 11'inin ölçek geliştirme ve 5'inin ölçek 
uyarlama olduğu sonucuna ulaşılmıştır. Bu bulgulardan hareketle makalelerde en fazla ilişkisel ve betimsel yöntemlerin tercih edildiği, en az ise nitel ve karma yöntemlerin tercih edildiği görülmektedir. Kariyer psikolojik danışmanlığı ve mesleki rehberlik alanında yayınlanan makalelerde tercih edilen araştırma yöntemleri ve makalelerin yayınlandığı yıllar arasındaki uyum ile ilgili olarak; satır (yıl) ve sütun (yöntem) değişkenleri arasında bir uyum olmadığ 1 tespit edilmiştir. Buna göre yıllar ve tercih edilen araştırma yöntemlerinin birbirinden bağımsız olduğu ve y1llar ile araştırma yöntemlerinin etkileşimini gösteren belirgin bir boyutlandırmanın yapılamayacağı söylenebilir. Araştırma sonucu benzer araştırma sonuçlarıyla paralellik göstermektedir. Sexton (1996: 592-593) bireysel psikolojik danışmanlık, kariyer psikolojik danışmanlığı ve okul danışmanlığı alanında 365 sonuç araştırmasının \%5'inden daha azının nitel araştırma yöntemlerini kullandığını rapor etmiştir. Stead, Perry, Munka, Bonnett, Shiban ve Care (2012: 112), 1999 ve 2009 yılları arasında, kariyer psikolojik danışmanlığı ve gelişimiyle ilgili 11 önde gelen dergide yayınlanan makaleleri içerik analizi ile incelemişler ve makalelerin \%55,9'unun nicel yönteme dayandığını bildirmişlerdir. Ayrıca makalelerin \%35,5'i, nitel araştırma ile ilgisi olmayan teorik çalışmalardır. Araştırma bulgularıyla paralel olarak, uzun süredir nicel yöntemlerin kariyer psikolojik danışmanlığı araştırmalarında daha fazla tercih edildiği (Fouad 2001: 184, Savickas 2001: 287) ve nitel yöntemlerin daha az kullanılmaya devam ettiği (Mcllveen, 2008: 13, Patton ve Mcllveen 2009: 148) literatürde vurgulanmaktadır. Kariyer psikolojik danışmanlığı ve mesleki rehberlik araştırmaları, nicel yöntemlere vurgu yaparak modern çağın kökenlerini yansıtsa bile kariyer teorisi ve pratiğinin, yapılandırmacı model ve yaklaşımları geliştirip benimsemeye başlaması (McMahon vd. 2006: 26) nedeniyle kariyer danışmanlığg ve mesleki rehberlik alanında nicel yöntemlerden farklı araştırma yöntemlerine ihtiyaç duyulmaktadır (McMahon, 2014: 16). Araştırma sonucuna göre ise Türkiye'de kariyer psikolojik danışmanlığı ve mesleki rehberlik alanındaki araştırmaların mantıksal pozitivist felsefenin etkisinde olduğu ve buna bağlı olarak nicel yöntemlere ağırlık vermesiyle modern çağın kökenlerini yansıttığı söylenebilir.

Kariyer psikolojik danışmanlığı ve mesleki rehberlik alanında yayınlanan makalelerdeki yazar sayısı ile ilgili olarak; makalelerin çoğunun tek yazarlı ve çift yazarlı olduğu sonucuna ulaşılmıştır. Güven, Kısaç, Ercan ve Yalçın (2009: 84), Türk PDR Dergisi'nin ilk otuz sayısında yayınlanan makaleleri inceledikleri çalışmada tek yazarlı makalelerin daha fazla olduğu sonucuna varmışlardır. Seçer, Ay, Ozan ve Yılmaz (2014: 49) tarafindan, 2007-2011 yillar1 arasinda Ulusal Akademik A $\breve{g}$ ve Bilgi Merkezi (ULAKBİM) veri tabanı ve Rehberlik ve Psikolojik Danışma alanında yayın yapan toplam 24 dergiyi incelenmiş ve yayınların büyük bir kısmının tek veya iki yazarlı olduğunu tespit etmişlerdir. $\mathrm{Bu}$ durumun kaynağı olarak akademik yükselmede bir ya da iki yazarlı çalışmaların puan getirisinin daha fazla olması gösterilebilir.

Kariyer psikolojik danışmanlığı ve mesleki rehberlik alanında yayınlanan makalelerin çalışma grubu ile ilgili olarak; en çok lise öğrencilerinden ve üniversite öğrencilerinden çalışma grubu seçildiği sonucuna varılmıştır. Araştırma sonucuyla paralel olarak Güven, Aslan ve Yıldız-Akyol (2017: 140) 2000-2016 yılları arasında Türkiye'de PDR alanında yapılan
255 doktora tezinde çalışma grubu olarak lisans öğrencileri üzerinde yürütülen araştırmaların ağırlıkta olduğunu tespit etmişlerdir. Demirtaş-Zorbaz, Kızıldağ ve Voltan-Acar (2016: 1770), 1978-2012 yılları arasında lisansüstü düzeyde hazırlanan grupla psikolojik danışma, grup rehberliği ve psiko-eğitsel temelli tez çalışmalarında en fazla ergenler üzerinde çalışıldığını belirtmişlerdir. Kariyer psikolojik danışmanlığı ve mesleki rehberlik alanında en çok lise öğrencileri ile çalışılması, ortaöğretim döneminde alan ve üniversite için bölüm seçme işlemlerinin öneminden kaynaklı olabilir. Araştırma sonucunun eğitim sistemi içinde kariyer psikolojik danışmanlığı çalışmalarının odağını yükseköğretime geçiş sürecinin oluşturduğu (Yeşilyaprak, 2012: 106) görüşünü desteklediği söylenebilir.

Kariyer psikolojik danışmanlığı ve mesleki rehberlik alanında yayınlanan makalelerdeki çalışma grubu sayısı ile ilgili olarak; en çok 201-300 arası, daha sonra 301-400 aras1 katılımcıyı içeren makalelerin çoğunlukta olduğu sonucuna ulaşılmıştır. Farklı araştırma sonuçlarının da benzer bulguları rapor ettiği görülmektedir. Güven ve Aslan (2018: 596) tarafindan yürütülen araştırmada en çok 301-600 katılımcıy1 içeren çalışma gruplarıyla araştırmaların yürütüldüğü tespit edilmiştir. Güven, Özhan, Kaynak ve Kurt-Demirbaş (2018: 200) tarafindan yapılan bir başka araştırmada makalelerin örneklem sayılarının çoğunlukla 201-400 katılımcı arasında değiştiği sonucuna ulaşılmıştır. Bu durumun nedeni olarak ilişkisel ve betimsel araştırmaların çoğunlukta olması gösterilebilir.

Kariyer psikolojik danışmanlığı ve mesleki rehberlik alanında yayınlanan makalelerde tercih edilen konu ve kavramlar ile ilgili olarak; en çok çalışılan kavramların iş doyumu ve mesleki olgunluk kavramları olduğu sonucuna ulaşılmıştır. $\mathrm{Bu}$ kavramların yanı sıra kariyer gelişimi, karar verme stilleri, mesleki tükenmişlik, kariyer karar verme yetkinliği kavramlarının da en çok çalışılan kavramlar arasında olduğu tespit edilmiştir. Benzer şekilde Güven ve Aslan (2018: 600), PDR alanında yayınlanan makalelerden mesleki rehberlik alanında en çok çalışılan konuların mesleki olgunluk ve iş doyumu olduğu sonucuna ulaşmışlardır. Sexton (1996: 595) bireysel psikolojik danışma, kariyer psikolojik danışma ve okul danışmanlığı alanında yürütülmüş 365 sonuç araştırmasını incelediği çalışmada, kariyer psikolojik danışmanlığı alanında en çok çalışılan konunun kariyer karar verme olduğunu tespit etmiştir. Whiston, Rose, Peterson ve Nguyen (2013: 372) ise sosyal bilişsel kariyer kuram1/öz yetkinlik teorisi ve Holland'ın kuramının, 1993'ten 2011'e kadar Journal of Career Assessment'daki teorik temelli makaleler için en sık kullanılan iki teori olduğunu rapor etmiştir. Benzer bir sonuç, The Career Development Quarterly dergisinde 2013 yılı içinde üç ayda bir yayınlanan makalelerin içerik analizinde de ortaya çıkmıştır (Sampson vd., 2014: 308). Ek olarak, Sampson vd. (2014: 294) iş doyumunu geçmişte vurgulanmayan, ancak son y1llarda The Career Development Quarterly dergisinde en fazla vurgulanan kavramlardan biri olarak listelemişlerdir. Oh, Stewart ve Phelps (2017: 608-611) 1963-2015 yılları arasında Journal of Counseling Psychology'de yayımlanmış 3603 makaleyi incelemişlerdir. $\mathrm{Bu}$ araştırmanın sonucunda, mesleki psikoloji alanında en fazla çalışılan konuların sırasıyla sosyal bilişsel kariyer kuramı, mesleki ilgi envanterleri, Holland'in modeli ve mesleki ilgiler, kariyer karar verme ve kariyer gelişimi, iş ve yaşam doyumu ile meslek seçimi olduğunu rapor etmiştir. 


\section{5. Öneriler}

Araştırmadan elde edilen bütün sonuçlar dikkate alındığında bazı önerilere yer verilebilir. Öncelikle, modern ve post modern yaklaşımlar arasında, kariyer araştırmalarının teorik ve felsefi kökenlerini yansıtan belirgin farklılıklar vardır. Bununla birlikte, bu farklılıklara rekabetçi bir anlamda odaklanmak yerine, iki geleneğin potansiyel tamamlayıcılıklarını, farklı ve değerli katkılarını dikkate almak önemlidir. İki geleneğin kariyer araştırmalarına, muhalif bir duruştan ziyade işbirlikçi bir yolla getirebilecekleri zenginlik (McMahon vd., 2006: 27) unutulmamalıdır. Tercih edilen mantıksal pozitivizme ve bununla birlikte bilme biçimlerine aşırı derecede güvenildiğinde, fenomenlerin empatik bir anlayışla ve yakın bir deneyimle anlaşılmasını sağlayan diğer bilgi kaynaklarına erişim kısıtlı hale gelir (Blustein, 2006: 199). Buradan hareketle nitel ve karma yöntem araştırmalarının, kariyer psikolojik danışmanlığı ve mesleki rehberlik alanında yaygınlaştırılması gerektiği açıktır. Aynı konuda yürütülmüş farklı araştırmaları birleştirerek ve toplam örneklem genişliğini arttırarak parametre kestirimlerinin kesinliğini ve gücünü arttırmak amacıyla meta analiz çalışmalarının yürütülmesi önerilmektedir. Kariyer psikolojik danışmanlığı ve mesleki rehberlik alanında özellikle çocuk ve ergen kariyer gelişimi ile ilgili soruların yanıtlanmasında boylamsal araştırmalara önem verilmelidir. Örneklem büyüklüğü ve örneklem gruplarına erişim ile ilgili sorunları aşmada web tabanlı ölçme araçları ve yardım uygulamaları geliştirmenin faydalı olacağı düşünülmektedir. Ölçek geliştirme çalışmaları arttırılarak kültüre uygun ölçme araçları alana kazandırılabilir. Araştırmaya dâhil edilme ölçütleri konusunda düzenlemeler yapılarak gelecek araştırmalarda daha geniş bir açıdan bakılabilir.

\section{Sinırlılıklar}

$\mathrm{Bu}$ araştırmanın, her ne kadar geniş bir zaman diliminde kariyer psikolojik danışmanlığı ve mesleki rehberlik alanında Türkiye'de yayınlanmış makalelerin detaylı görünümünü vermede önemi olsa da göz önünde bulundurulması gereken bazı sınırlılıkları vardır. İlk olarak bu araştırmanın sonuçlarını, kariyer psikolojik danışmanlığı ve mesleki rehberlik alanında Türkiye'de yayınlanmış makalelerin tamamının görünümü şeklinde değerlendirmek yanlış olur. $\mathrm{Bu}$ araştırma, 2002-2017 yılları arasında yayınlanmış makalelerle sınırlıdır. İkincisi; Ulusal Akademik Ağ ve Bilgi Merkezi (ULAKBIM), Türkiye'de araştırma faaliyetlerinin en önemli çıkış noktalarından biridir. Ancak tüm resmin yalnızca bir kısmıdır. $\mathrm{Bu}$ nedenle, bu araştırmanın bulgularını, diğer ilgili veri tabanlarının araştırma geçmişleri ile tamamlayarak daha fazla fayda elde edilebilir. Kariyer psikolojik danışmanlığı ve mesleki rehberlik ile ilgili araştırmalar; hemşirelik, çalışma ekonomisi, iktisat, büro yönetimi, eğitim bilimlerinin diğer anabilim dallarında vb. birçok alanda yürütülmektedir. Bu araştırma kapsamına giren makaleler belirlenirken yazarlarının PDR alanında görev yapıyor olmaları ya da bu alanda eğitim görmüş olmaları şartının göz önünde bulundurulması, araştırmanın üçüncü sınırlılığıdır. Son olarak, araştırma kapsamına girebilecek çok az da olsa bazı çalışmaların sadece özet metinlerine erişim sağlanabilmiştir. Araştırma için gerekli bilgilerin tamamının özet metinlerinde yer almaması sebebiyle makalelerin yazarlarıyla iletişime geçilmeye çalışılmıştır. Ancak hiçbir yazarın dönüt sağlamamış olması, bu makalelerin araştırma kapsamına alınamamasına neden olmuştur.

\section{Kaynakça}

Bacanlı, F. (2011). Özellik faktör uyumlu kuramlar. İçinde B. Yeşilyaprak (Ed.), Mesleki rehberlik ve kariyer danışmanlı̆̆ kuramdan uygulamaya (ss. 90-133). Ankara: Pegem Akademi.

Bartholomew, D. J., Steele, F., Muostaki, I., \& Galbraith, J. (2008). Analysis of multivariate social science data (2th edition). Florida: Chapman \& Hall.

Blustein, D. (2006). The psychology of working. A new perspective for career development, counseling, and public policy. Mahwah, NJ: Lawrence Erlbaum.

Brown, D. (2002a). The role of work and cultural values in occupational choice, satisfaction, and success: A theoretical statement. Journal of Counseling and Development, 80(1), 48-56.

https://doi.org/10.1002/j.1556-6678.2002.tb00165.x

Brown, D. (2002b). Introduction to theories of career development and choice. Origins, evolution and current efforts. In D. Brown \& Associates (Eds.), Career choice and development (4th ed., pp. 3-23). San Francisco: Jossey Bass.

Brown, D., \& Crace, R. K. (1996). Values in life role choices and outcomes: A conceptual model. The Career Development Quarterly, 44(3), 211-223.

https://doi.org/10.1002/j.2161-0045.1996.tb00252.x

Brott, P. E. (2001). The storied approach: A postmodern perspective for career counseling. The Career Development Quarterly, 49(4), 304-313. https://doi.org/10.1002/j.2161-0045.2001.tb00958.x

Brott, P. E. (2005). A constructivist look at life roles. The Career Development Quarterly, 54(2), 138-149. https://doi.org/10.1002/j.2161-0045.2005.tb00146.x

Cohen, L., Manion, L., \& Morrison, K. (2007). Research methods in education (6th ed.). New York, NY: Routledge.

Çarkıt, E. (2019). Kariyer danışmanlığı ve mesleki rehberlik alanında Türkiye'de yapılan lisansüstü tezlerin araştırma eğilimleri. Manas Sosyal Araştırmalar Dergisi, 8(2), 1503-1514. https://doi.org/10.33206/mjss.493303

Demirtaş-Zorbaz, S., Kızıldağ, S., \& Voltan-Acar, N. (2016). Türkiye'deki üniversitelerde lisansüstü düzeyde yapılan grup çalışmalarının incelenmesi. Kastamonu Eğitim Dergisi, 24(4), 1765-1784.

Duffy, R., \& Sedlacek, W. (2007). What is most important to students' long-term career choices: Analyzing 10-year trends and group differences. Journal of Career Development, 34(2),149-163. https://doi.org/10.1177/0894845307307472

Fouad, N. (2001). The future of vocational psychology: Aiming high. Journal of Vocational Behavior, 59, 183191. https://doi.org/10.1006/jvbe.2001.1824 
Güven, M., \& Aslan, A. M. (2018). Psikolojik danışma ve rehberlik alanında türkiye'deki bilimsel dergilerde yayınlanan makaleler üzerine bir inceleme. Uluslararast Sosyal Araştırmalar Dergisi, 11(5), 592-604. https://dx.doi.org/10.17719/jisr.20185537232

Güven, M., Aslan, B., \& Yıldız Akyol, E. (2017). Türkiye’de psikolojik danışma ve rehberlik alanında yapılan doktora tezlerinin incelenmesi (2000-2016). Ĕgitim ve Öğretim Araştırmaları Dergisi, 6(3), 136-147.

Güven, M., Kısaç, İ., Ercan, L., \& Yalçın, İ. (2009). Türk Psikolojik Danışma ve Rehberlik Dergisi'nde yayınlanan makalelerin çeşitli özellikler açısından incelenmesi. Türk Psikolojik Danışma ve Rehberlik Dergisi, 4(31), 80-87.

Güven, M., Özhan, M. B., Kaynak, S., \& Kurt Demibaş, N. (2018). Türk Psikolojik Danışma ve Rehberlik Dergisi ile Journal of Counselling Psychology'deki araştırma eğilimleri. Türk Psikolojik Danışma ve Rehberlik Dergisi, 8(49), 193-208.

Johnson, R., \& Wichern, D. (2007). Applied multivariate statistics. (6th edition). Prentice-Hall, Upper Saddle River, NJ, USA.

Keldal, G., \& Bilge, F. (2016). Psikolojik danışma ve rehberlik alanında karma yöntemli araştırmalar: Bir içerik analizi çalışması, Ö. Demirel ve S. Dinçer (Ed.), Ĕgitim Bilimlerinde Yenilikler ve Nitelik Arayışı (s. 643-654). Ankara: Pegem Akademi.

Korkut-Owen, F. \& Niles, S. G. (2011). Yeni yaklaşımlar ve modeller. İçinde B. Yeşilyaprak (Ed.). Mesleki rehberlik ve kariyer danışmanlığ kuramdan uygulamaya (ss. 274307). Ankara: Pegem Akademi.

Mcllveen, P. (2008). Autoethnography as a method for reflexive research and practice in vocational psychology. Australian Journal of Career Development, 17(2), 13-20. https://doi.org/10.1177/103841620801700204

McMahon, M. (2014). New Trends in Theory Development in Career Psychology, In G. Arulmani, A. J. Bakshi, F. T. Leong, \& A. G. Watts (Eds.), Handbook of career development: International perspectives (pp. 13-27). Springer Science \& Business Media.

McMahon, M., \& Watson, M. (2006). Career research in a post-modern era. Australian Journal of Career Development, 15(1), 26-31. https://doi.org/10.1177/103841620601500206

McMahon, M., \& Watson, M. (2007). An analytical framework for career research in the post-modern era. International Journal for Educational and Vocational Guidance, 7(3), 169-179.

https://doi.org/10.1007/s10775-007-9126-4

Oh, J., Stewart, A. E., \& Phelps, R. E. (2017). Topics in the Journal of Counseling Psychology, 1963-2015. Journal of counseling psychology, 64(6), 604-615. http://dx.doi.org/10.1037/cou0000218

O'Leary, Z. (2004). The essential guide to doing research. London, New Delhi: SAGE Publications.

Patton, W. \& McMahon, M. (1999). Career development and systems theory: A new relationship. Thomson Brooks/Cole Publishing Co.
Patton, W., \& McIlveen, P. (2009). Practice and research in career counseling and development-2008. The Career Develeopment Quarterly, 58(2), 118-161. https://doi.org/10.1002/j.2161-0045.2009.tb00052.x

Sampson Jr, J. P., Hou, P. C., Kronholz, J. F., Dozier, V. C., McClain, M. C., Buzzetta, M., ... \& Reardon, R. C. (2014). A content analysis of career development theory, research, and practice-2013. The career development quarterly, 62(4), 290-326. https://doi.org/10.1002/j.21610045.2014.00085.x

Savickas, M. (2001). The next decade in vocational psychology: Mission and objectives. Journal of Vocational Behavior, 59(2), 284-290. https://doi.org/10.1006/jvbe.2001.1834

Savickas, M. L. (2002). Career construction: A developmental theory of vocational behavior. In D. Brown ve ark. (Ed.), Career choice and development (ss. 149-205). San Francisco: Jossey Bass.

Savickas, M. (2008). Helping people choose jobs: A history of the guidance profession. In J. A. Athanasou \& R. Van Esbroeck (Eds.), International handbook of career guidance (pp. 97-113). Dordrecht, the Netherlands: Springer Science.

Savickas, M. L., Laura, N., Rossier, J., Dauwalder, J-P., Duarte, M. E., Guichard, J., ... Van Vianen, A. (2009). Life designing: A paradigm for career construction in the 21 st century. Journal of Vocational Behavior, 75(3), 239250. https://doi.org/10.1016/j.jvb.2009.04.004

Seçer, İ., Ay, İ., Ozan, C., \& Yılmaz, B. Y. (2014). Rehberlik ve psikolojik danışma alanındaki araştırma eğilimleri: Bir içerik analizi. Türk Psikolojik Danışma ve Rehberlik Dergisi, 5(41), 49-60.

Sexton, T. (1996). The relevance of counseling outcome research: Current trends and practical implications. Journal of Counseling \& Development, 74, 590-600. https://doi.org/10.1002/j.1556-6676.1996.tb02298.x

Sharf, R. S. (2017). Kariyer gelişim kuramlarının kariyer danışmasına uygulanması. (F. Bacanlı \& K. Öztemel, Çev. Edt.). Ankara: Pegem Akademi.

Stead G. B., Perry, J. C., Munka, L. M., Bonnett, H. R., Shiban, A. P., \& Care, E. (2012). Qualitative research in career development: Content analysis from 1990 to 2009. International Journal for Educational and Vocational Guidance, 2(12), 105-122. https://dx.doi.org/10.1007/s10775-011-9196-1

Türk, F., \& Cihangiroğlu, Ü. (2018). Thematic and methodological investigation of applied postgraduate theses on psychological counseling and guidance. International Journal of Eurasia Social Sciences, 9(31), 276-311.

Watson, M., \& McMahon, M. (2005). Editorial: Postmodern (narrative) career counselling and education. Perspectives in Education, 23(1), vii-ix. https://hdl.handle.net/10520/EJC87322

Watson, M., \& Stead, G. (2006). An overview of career theory. In G. B. Stead \& M. B. Watson (Eds.), Career 
psychology in the South African context (2nd ed., pp. 1334). Pretoria, South Africa: Van Schaik.

Whiston, S., Rose, C. S., Peterson, J. M., \& Nguyen, C. P. (2013). Content analysis of the Journal of Career Assessment. Journal of Career Assessment, 21(3), 367377. https://doi.org/10.1177/1069072712475160
Yeşilyaprak, B. (2011). Mesleki Rehberlik ve Kariyer Danışmanlığı Kuramdan Uygulamaya. Ankara: Pegem Akademi.

Yeşilyaprak, B. (2012). Mesleki rehberlik ve kariyer danışmanlığında paradigma değişimi ve Türkiye açısından sonuçlar: Geçmişten geleceğe yönelik bir değerlendirme. Kuram ve Uygulamada Eğitim Bilimleri, 12(1), 